\title{
Correction to: Simulated weightbearing computed tomography for verification of radiographic staging of varus ankle osteoarthritis: a cross-sectional study
}

\author{
Kiyonori Tomiwa ${ }^{*}$, Yasuhito Tanaka ${ }^{1}$, Hiroaki Kurokawa ${ }^{1}$, Kunihiko Kadono ${ }^{1}$, Akira Taniguchi ${ }^{1}$ and
} Korakot Maliwankul ${ }^{2}$

Correction to: BMC Musculoskelet Disord 22, 737 (2021)

https://doi.org/10.1186/s12891-021-04618-6

Following the publication of the original article [1] the authors noticed that the errors pointed out in Table 3 were not implemented. The original article [1] has been updated.

Below is the correct Table 3.

Table 3 Direction of subluxation and row with maximum damage on the distal articular surface

\begin{tabular}{lll}
\hline Stage & Subluxation & $\begin{array}{l}\text { Row with maximum damage } \\
\text { on the distal articular surface }\end{array}$ \\
\hline 3a & anteriorly 5 & none 5 \\
& posteriorly 9 & posterior 5 , none 4 \\
none 12 & posterior 2, none 10 \\
\hline 3b & anteriorly 22 & anterior 22 \\
& posteriorly 12 & posterior 12 \\
& none 23 & anterior 11, posterior 9, central 3 \\
\hline
\end{tabular}

\section{Author details}

${ }^{1}$ Department of Orthopedic Surgery, Nara Medical University, 840 Shijo, Kashihara, Nara 634-8522, Japan. ${ }^{2}$ Department of Orthopedics, Prince of Songkla University, 15 Karnjanavanich Road, Hat Yai, Songkhla 90110, Thailand.

Published online: 13 October 2021

\section{Reference}

1. Tomiwa K, Tanaka Y, Kurokawa H, et al. Simulated weightbearing computed tomography for verification of radiographic staging of varus ankle osteoarthritis: a cross-sectional study. BMC Musculoskelet Disord. 2021;22:737. https://doi.org/10.1186/s12891-021-04618-6.

Full list of author information is available at the end of the article permits use, sharing, adaptation, distribution and reproduction in any medium or format, as long as you give appropriate credit to the original author(s) and the source, provide a link to the Creative Commons licence, and indicate if changes were made. The images or other third party material in this article are included in the article's Creative Commons licence, unless indicated otherwise in a credit line to the material. If material is not included in the article's Creative Commons licence and your intended use is not permitted by statutory regulation or exceeds the permitted use, you will need to obtain permission directly from the copyright holder. To view a copy of this licence, visit http://creativecommons.org/licenses/by/4.0/. The Creative Commons Public Domain Dedication waiver (http://creativeco mmons.org/publicdomain/zero/1.0/) applies to the data made available in this article, unless otherwise stated in a credit line to the data. 